\title{
Mito e Historia: Dos Generadores del Canto General
}

Dos poéticas coexisten en el Canto general de Pablo Neruda, dos conformaciones verbales diferentes, quizá antagónicas; provienen de dos distintas visiones del mundo que condicionan dos percepciones y dos expresiones disímiles. Son como polos opuestos de atracción, dos extremos entre los cuales tota y se traslada el mundo poético de Neruda.

Neruda es un poeta visionario, es decir movido por una voluntad de representación, de figuración, por un afán icónico, afán de transmitir imágenes. La poesía no constituye para él un objeto y objetivo autónomos, una entidad autosuficiente, autorreferente, sino un medio para comunicar mensajes que nos remiten a instancias no textuales. Neruda no es un formalista, nunca se detiene demasiado en lo verbal intrínseco. Siempre apunta a realidades, es decir evidencias subjetivas u objetivas, personales, naturales, sociales, de las cuales su palabra es signo, signo que significa en función de su proximidad o fidelidad con respecto a lo significado.

El mensaje de Neruda informa no sólo sobre el mundo, también sobre el acto de percibirlo y sobre el instrumento de percepción. La poesía de Neruda se quiere realista (en tanto pretende transmitir un cierto conocimiento sobre ese vasto acaecer que someramente llamamos realidad), personal (en tanto expresa un yo que no se despersonaliza, que quiere conservar la impronta subjetiva, la vibración emotiva, volitiva, patética, egocéntrica aunque sea equívoca, enrarecedora, perturbadora de lo cognoscitivo, factor de entropía; para Neruda, ese yo patético es garante de autenticidad, contrario a la neutralidad abstracta, a la clasificación categorial, a la causalidad científica, a la concatenación lógica, sinónimos de artificio, de desvirtuación de la percepción original, oscura, intuitiva, espontánea, caótica); la poesía de Neruda se quiere estética (en tanto sujeta a una formalización gráfica, rítmico-sonora, léxica, sintáctica, a una funcionalidad especial tendiente a comunicar información intrínsecamente 
poética). Realidad, percepción y expresión cambian de una poética a otra. La una presenta un mundo permanente, natural a través de una visión mítica, primitiva, arcaizante y mediante un lenguaje metafótico, oscuro, oracular; la otra presenta un mundo histórico, social, progresivo, a través de una visión no personal, que se quiere objetiva, y mediante un lenguaje claro y unívoco.

Existe en el Canto general un sustrato poético basamental, corres. pondiente a la personalidad profunda del poeta. No ignoro los implí. citos psicológicos de esta afirmación, pero la creo adecuada a una poesía reveladora de los abismos de la conciencia, una paesía rapsódica, cuyo movimiento predominante es el descendimiento hacia lo oscuro, hacia lo entrañable, hacia lo preformal, hacia lo preverbal o por lo menos preoral, tal como lo expresa insistentemente el mismo Neruda en múl. tiples textos. Ya me he acupado en cercar, definir e interpretar esta poética mítico-metafórica, desde los poemas iniciales hasta Residencia en la tierra. ${ }^{1}$ Ella se prolonga, invade el Canto general y continúa subyacente o aflorada, a lo largo de toda la obra nerudeana.

El otro generador es el de la poética militante-testimonial, 2 regida por una voluntad política, ideológica, pedagógica que lo mueve a em. prender una crónica de América para exaltar sus grandezas y condenar sus lacras, reseñar su historia como enfrentamiento permanente entre opresores y liberadores, reivindicar, iluminar y coaligar a los oprimidos, incitarlos a la definitiva conquista de su independencia, vaticinar el porvenir.

En primer abordaje, desde la lectura inicial, comprobamos en el Canio genteral que la escritura alterna entre poemas herméticos, muy plurivalentes, de gran densidad metafórica, de intrincada tesitura semántica, cuya sugestión proviene en gran parte de su agitada indeterminación:

Mientras tanto en tu edad sobrevivieron

las aspas del transcurso sumergido,

y la creada magnitud mantiene

las mismas esmeraldas escamosas,

los abetos hambrientos que devoran

con bocas azuladas de sortija,

I V. "La imaginación mitológica de Pablo Neruda" en Fundadores de la nueva poesía latinoamericana, Barral Editores, Barcelona, 1971, pp. 141 y ss.

2 No me ocuparé aquí de su estudio diacrónico. Ya lo han hecho acertadamente Hernán Loyola en Ser y morir en Pablo Neruda, Editorial Santiago, Sgo. de Chile, 1967, y Emir Rodriguez Monegal en El viajero inmóvil. Introducción a Pablo Neruda, Losada, Buenos Aires, 1966. 
el cabello que absorbe ojos ahogados, la madrépora de astros combatientes, y en la fuerza aceitada del cetáceo se desliza la sombra triturando.

\section{(El gran océdno, II)}

y otros que se aproximan al máximo a la elocución prosaria, donde el lenguaje se simplifica, se vuelve directo, discursivo, verista, fáctico, referencial (es decir, destinado ante todo a comunicar hechos verificables, extratextuales, con el mínimo de estilo, de expresividad, de perturbaciones subjetivas o formales):

Cuando llegan de Nueva York

las avanzadas imperiales, ingenieros, calculadores, agrimensores, expertos, y miden tierra conquistada, estaño, petróleo, bananas, nitrato, cobre, manganeso, azúcar, hierro, caucho, tierra, se adelanta un enano oscuro, con una sonrisa amarilla, y aconseja, con suavidad, a los invasores recientes:

No es necesario pagar tanto

a estos nativos, sería torpe, señores, elevar estos salarios. No conviene.

Estos rotos, estos cholitos no sabrian sina embriagarse con tanta plata. No, por Dios.

Son primitivos, poco mas que bestias, los conozco mucho. No vayan a pagarles tanto.

Es adoptado. Le ponen librea. Viste de gringo, escupe como gringo. Baila como gringo, y sube. 
He tomado muestras extremas, las dos puntas del espectro del rapto alucinado al simplismo épico. Las dos poéticas priman alternativamente en uno u otro canto, o dentro de cada canto, en uno u otro poema. A veces alternan en un mismo poema. Otras veces, las menos, se produce la amalgama, el intento de conciliar ensoñación cosmogónica con el realismo historicista. ${ }^{3}$

Aunque es uno de los pocos libros programáticos de Neruda, produ. cido no sólo aluvionalmente por la acumulación de poemas que corresponden a un registro o a una época, el Canto general carece de articulación rigurosa, de ordenamiento simétrico razonadamente articulado (cronológico, anecdótico o temático), que disponga el material concatenándolo en función de un desarrollo, de un despliegue progresivo, de un continuo lógico. Es a la vez cosmogénesis, geografía, rito, crónica, panfleto, fabulación, arenga, sátira, autobiografía, rapto, alucinación, profecía, conjuro, testamento. Responde a una estructura abierta, multiforme, politonal, proclive a las mezclas, a las superposiciones y reiteraciones.

Creo que la dificultad de fusionar ambas poéticas proviene de su oposición irreconciliable. La una, la mítica, postula un retroceso, un regreso al útero, una vuelta al origen que privilegia el pasado; es una versión nostálgica, alimentada por el deseo de recobrar la plenitud del comienzo; nos sitúa en el tiempo natural, cíclico, sin progreso, el del eterno retorno, donde todo es transferible, reversible, recuperable, donde nacimiento y muerte son intercambiables. La otra, la poética historicista, presupone un tiempo prospectivo, de continuo avance, vectorial, dirigido a un futuro donde se sitúa la plenitud; la edad de oro no estát al principio sino al final, una vez consumada la revolución social. La historia es un motor que puja, a través de una empedernida y accidentada superación de obstáculos, hacia la consecución de ese objetivo venturoso.

Una poética ensalza la vida natural, la plenitud del adamita armónicamente integrado al universo que prolonga el seno materno, protector, nutricio; pondera la visión elemental, virginal, infantil, ingenua, totalizadora (ni diferenciadora ni objetivadora); menosprecia la ciencia abs-

3 Es erróneo suponer, como lo quiere Neruda, que en el Canto general se opera el esforzado pasaje de la oscuridad a la claridad (V. en E. Rodríguez Monegal, op. cit., pp. 146-147, fragmentos del discurso de Neruda ante el Congreso Continental de la Cultura realizado en Santiago en 1953) como una especie de crecimiento biológico, de modo que los pasajes herméticos serían temporalmente anteriores a los claros y directos. La confrontación cronológica prueba de inmediato la coexistencia de los dos tipos de discurso, tributarios respectivamente de la poética mítica y la militante. La veta míti-metafórica no desaparece a partir del Canto general, sigue emergiendo hasta en los libros más recientes (La espada encendida, por ejemplo); es constitutiva y constante de la imaginación nerudeana. 
tracta, la cultura libresca, el desarrollo tecnológico, la civilización urbana. La otra poética es voluntarista; celebra el trabajo humano por dominar la naturaleza; el avance industrioso, las modificaciones del habitat del hombre aportadas por la acumulación de experiencia técnica, la comprensión científica, la máxima inteligibilidad del universo, la planificación a escala planetaria, la práctica lúcida asentada en un continuo esclarecimiento teórico, la muerte de la metafísica, el fin de los dogmas y de las supersticiones, la utopía racionalista.

Por un lado el discurso mítico-metafórico, intrincado, exuberante, caótico, librado a la energía metamórfica de una imaginación naturalizante, penetrante, materializante, orgiástica, que a todo dota de animación biológica, que ansía concordar a través de la fabulación turbulenta, del ritual rapsódico con las fuerzas genésicas del cosmos; que alucinadamente, activada al máximo de su potencia verbal, sueña con captar por salto simpático, por inmersión in media res, por instalación en el núcleo primordial, en el centro energético, las creaciones y destrucciones de la tierra y el mar en el pináculo de su mutabilidad:

Aquí estoy, aquí estoy, boca humana entregada al paso pálido de un detenido tiempo como copa o cadera, central presidio de agua sin salida, árbol de corporal flor derribada, únicamente sorda y brusca arena.

- Patria mía, terrestre y ciega como nacidos aguijones de la arena, para ti toda la fundación de mi alma, para ti los perpetuos párpados de mi sangre, para ti de regreso mi plato de amapolas.

Dame de noche, en medio de las plantas terrestres, la huraña rosa de rocío que duerme en tu bandera, dame de luna o tierra tu pan espolvoreado con tu temible sangre oscura:

bajo tu luz de arena no hay muertos, sino largos ciclos de sal, azules ramas de misterioso metal muerto. 
Por otro lado el discurso político, prosario, de máxima determinación semántica, unívoco, la poética de denuncia, explicitud y aplanamiento, simplificación, despojamiento, retórica de lo directo para corresponder a las urgencias de la historia inmediata, para extraer fogosidad del presente candente. Poesía combativa, utilitaria, es arma y herramienta. El medio se neutraliza en función de la trascendencia del mensaje; la palabra debe ser cristal que transparente con nitidez lo que se mire. La poesía se pone al servicio de una verdad externa. Su mérito está en relación directa con la veracidad, con la gravitación de la realidad representada:

En Lota están las bajas minas

del carbón: es un puerto frío, del grave invierno austral, la lluvia

cae y cae sobre los techos, alas de gaviotas color de niebla, y bajo el mar sombrío el hombre cava y cava el recinto negro.

La vida del hombre es oscura como el carbón, noche andrajosa, pan miserable, duro día.

Yo por el mundo anduve largo, pero jamás por los caminos - las ciudades nunca vi más maltratados a los hombres. Doce duermen en una pieza. Las habitaciones tienen techos de restos sin nombre: pedazos de hojalata, piedras, cartones, papeles mojados. Niños y perros en el vapor húmedo de la estación fría, se agrupan hasta darse el fuego de la pobre vida que un día será otra vez hambre y tinieblas.

(La arena traicionada, IV)

Una y otra poética se explicitan en múltiples pasajes del Canto general, en los que la poesía se vuelve sobre sí misma. Neruda poetiza sobre el 
acto de poetizat. A través de este metalenguaje (lenguaje autorreflexivo), se nota bien la disyunción del Canto en dos estéticas. Vamos a codificar primero las referencias relativas a la poética mítica.

Para ésta, la poesía es una emanación de la naturaleza. El flujo poético es un estro equiparable a todas las fluencias naturales: agua, savia, sangre, semen. Hunde sus raíces en la tierra, sobre todo la natal, de donde extrae su sustancia nutricia; de ella proviene la inspiración significativa, la energía que se transformará en canto:

Tierra mía sin nombre, sin América, estambre equinoccial, lanza de púrpura, tu aroma me trepó por las raíces hasta la copa que bebia, hasta la más delgada palabra aún no nacida de mi boca.

(La lampara en la tierra, "Amor América")

El poema no es trabajosa producción, forjadura de una voluntad consciente, sino formación natural, latencia que, resurgiendo del barro primordial, un día germina:

$Y$ así de tierra a tierra fui tocando

el barro americano, mi estatura, y subió por mis venas el olvido recostado en el tiempo, hasta que un día estremeció mi boca su lenguaje.

(Yo soy, XII)

Telúrico, oceánico, el poema es siempre engendramiento de una fuerza natural: "mi corazón se recogió en su copa/ y extendió hacia los mares y las plumas/ la desembocadura de su canto". Todo lo natural es significante $y$ lo no natural insignificante. Ni el lenguaje ni la poesía son privativos del hombre. La naturaleza entera habla, es un texto legible sólo para aquéllos que ella destinó como sus portavoces; es una emisora de mensajes cifrados, secretos (adjetivo abundantísimo en los poemas de Neruda), enigmáticos, perceptibles sobre todo para los dotados por ella del don del canto. Refiriéndose a la quila, dice Neruda: ".. .Cuando paso por tu follaje/ murmuran la dureza, y despiertan palabras/ que hieren, silabas que amamantan espinas". (Canto general de Chile, IX). 
El poeta es el elegido para actuar de intermediario entre las fuerzas cósmicas y los otros hombres:

Pero háblame, Bío Bío, son tus palabras en mi boca las que resbalan, tú me diste el lenguaje, el canto nocturno mezclado con lluvia y follaje. Tú, sin que nadie mirara a un niño, me contaste el amanecer de la tierra, la poderosa paz de tu reino, el hacha enterrada con un ramo de flechas muertas, lo que las hojas del canelo en mil años te relataron, y luego te vi entregarte al mar dividido en bocas y senos, ancho y florido, murmurando una historia color de sangre.

\section{(La lámpara en la tierra, IV)}

La poesía es un camino de conocimiento sustancial pero oscuro, el talismán que pone en contacto con el centro energético de donde dimana toda creación, el medio para descender, penetrar y compenetratse con las fuerzas genésicas situadas en las entrañas de la materia. Para establecer esta comunicación se necesita entrar en trance, sufrir una especie de muerte iniciática que posibilite el retorno a las fuentes, hundirse "en lo más genital de lo terrestre", volver al comienzo, al "amanecer de la tierra", retornar a la argamasa primordial, predecesora de toda conformación, al "fondo del agua magna", al magma, a la "americana/sabana seminal, bodega espesa". Hay que ensimismarse; oscurecido, dormido, naufragar:

Entre los estudiantes pasé sin comprender, reconcentrando en mí las paredes, buscando cada tarde en mi propia poesía las ramas, las gotas y la luna que se habían perdido. Acudí al fondo de ella, sumergiéndome cada tarde en sus aguas, agarrando impalpables estímulos, gaviotas de un mat abandonado, 
hasta cerrar los ojos y naufragar en medio de mi propia sustancia.

(Yo soy, IV)

Hay que entrar "a la uterina/originalidad de la tierra", hasta alcanzar la matriz procreadora:

Solo, en las soledades

quiero llorar como los ríos, quiero

oscurecer, dormir

como tu antigua noche mineral.

Te hablo dormido, llamando

de tierra a tierra, madre

peruana, matriz cordillera.

Inmóvil en tus manos, siento extenderse los metales en los canales del subsuelo.

Estoy hecho de tus raíces, pero no entiendo, no me entrega la tierra su sabiduría, no veo sino noche $y$ noche bajo las tierras estrelladas.

(Los conquistadores, XVI)

Pero la revelación es indecible. El poeta vislumbra confusamente; ve movimientos enmarañados, superpuestos, caóticos; su visión no puede ser clarificada sin perder intensidad, movilidad, pujanza. No le queda sino representarla sugestivamente en su inestable, cambiante, simultánea aglomeración mediante el lenguaje oracular, mediante la urdimbre metafórica, mediante las efusiones, las proteicas fabulaciones de la imaginación metafórica:

La larga noche, el pino, viene adonde voy.

$\mathrm{Y}$ se trastorna el ácido sordo, la fatiga,

la tapa del tonel, cuanto tengo en la vida. Una gota de nieve llora y llora en mi puerta mostrando su vestido claro y desvencijado 
de pequeño cometa que me busca y solloza. Nadie mire la ráfaga, la extensión, el aullido del aire en las praderas.

Me acerco y digo: vamos. Toco el Sur, desemboco en la arena, veo la planta seca y negra, todo raíz y roca, las islas arañadas por el agua y el cielo, el Río del Hambre, el Corazón de Ceniza, el Patio del Mar Lúgubre, y donde silba la solitaria serpiente, donde cava el último zorro herido y esconde su tesoro sangriento encuentro la tempestad y su voz de ruptura, su voz de viejo libro, su boca de cien labios, algo que me dice, algo que el aire devora cada día.

(Los conquistadores, XXIV)

Neruda practica una empedernida naturalización de la poesía. Con "boca de diamante", en "sílabas de platino", el poeta escribe "páginas de agua". Su canto es maíz, raíz, semilla, transmite "las voces profundas de la tierra y el agua". Alternativamente se vegetaliza o mineraliza:

Brito, por las paredes capitales, entre el rumor de las cafeterías, andabas como el árbol peregrino buscando tierra con los pies profundos, hasta que fuiste haciéndote raíces, piedra y terrón y minería oscura.

(La tierra se llama Juan, VI)

Brito, poeta popular, se metamorfosea, cambia de estado como una energía natural. Todo el canto XII, Los rios del canto, está consagrado a los poetas amigos de Neruda, terrestres y fluviales, consubstanciados vitalmente con las materias primigenias. Este afán naturalizante de Neruda implica una suspensión de la conciencia reflexiva, una actitud anti-intelectual, un ahínco en lo espontáneo, lo instintivo, lo prerracional, una obstinación en la iluminación intuitiva, y por ende el menosprecio de la intelección, del pensamiento abstracto, de la crítica y la teoría literaria:4

4 Poco o ningún esclarecimiento de su oscura simbología, de sus intenciones ha brindado Neruda a sus exégetas. Es desdeñosa con aquéllos que quieren abordar 
Otras gentes se acostaron entre las páginas durmiendo como insectos elzevirianos, entre ellos se han disputado ciertos libros recién impresos como en el foot-ball, dándose goles de sabiduría. Nosotros cantamos entonces en la primavera, junto a los ríos que arrastran piedras de los Andes, y estábamos trenzados con nuestras mujeres sorbiendo más de un panal, devorando hasta el azufre del mundo.

(Canto general de Cbile, XIV)

Esta es la poética de la eternidad natural que reitera los mismos arquetipos, remitidos al principio de su génesis, parangonados con el modelo por antonomasia de toda creación: la cosmogonía. Todo nacimiento, toda factura, toda producción humana básica (como la poesía) reedita el nacimiento del mundo. Paul Robeson canta "como el comienzo del mar y de la vida", Neruda escribe "para una tierra recién secada, recién/ fres. ca de flores, de polen, de argamasa." El Canto general comienza por una cosmogonía telúrica - La lámpara en la tierra-y concluye por una acuática - El gran océano-; en su transcurso abundan los poemas que rememoran el "día de origen". La repetición de los mismos mode. los, de los mismos acontecimientos ejemplares, es consubstancial a la visión mítica, concepción sobre todo arquetipal, que anula las singulari. dades individuales. Para ella lo que vale es lo que se repite, o sea lo permanente. Lo original, desde esta perspectiva, es literalmente volver al origen, reiterar lo que desde el comienzo de los tiempos se instaura como modelo sacralizado.

Pero el mundo está mal hecho o por lo menos se aleja demasiado del modelo edénico; está deșirtuado, desnaturalizado por el abuso, la rapacidad de poderosos grupos humanos, por la desigualdad, por la injusticia social. Neruda, poeta de un continente cuyos pueblos han sido condenados al despojo, a la miseria y el estancamiento, habitante de un mundo explotado, expoliado por la voracidad capitalista, no se puede contentar con la visión natural, primitiva, paradisíaca. Adhiere a un partido proletario y quiere que su poesía pase del mito a la historia, de la evocación nostálgica al combate, de la oscuridad a la claridad, de la alienación individualista a la militancia colectiva, de la soledad a la solidaridad. E intentará ese tránsito no sólo en la acción externa, tam-

críticamente su obra. Nunca ha mostrado su taller, quizá para conservar la imagen del inspirado cuyos poemas brotan como el follaje, caen como las lluvias del sur, afloran como aguas surgentes. 
bién en su escritura. Sus propósitos transformadores están expresados en abundantes pasajes del Canto general, como contrapunto con la poética mitológica.

El paso de una a otra poética es notorio en Alturas de Macchu Picchu, ${ }^{5}$ notorio y a la vez imprevisto. De pronto, la visión nerudeana cambia de rumbo, pasa de la idealización del mundo incaico a la conciencia de sus injustas diferencias de clase. A partir del poema $\mathrm{X}$, la versión ritual, dignataria, mayestática se trastoca en historicista, realista, popular. De la obra magna, del santuario, de la cúspide de la pirámide desciende a la base sojuzgada, a sus constructores esclavizados, de los dinastas aniquiladores a los siervos enterrados, olvidados:

Macchu Picchu, pusiste piedras en la piedra, y en la base, harapo?

Carbón sobre carbón, y en el fondo la lágrima?

Fuego en el oro, y en él, temblando el rojo goterón de la sangre?

Devuélveme el esclavo que enterraste!

Sacude de las tierras el pan duro

del miserable, muéstrame los vestidos

del siervo y su ventana.

Luego hay otra muerte iniciática, un tito fúnebre, el descenso al mundo de los muertos, a la noche de piedra, la regresión a las tinieblas infernales; ésta to va a ser una purificación como el bautismo ${ }^{6}$-inmersión, disolución, emergencia, regeneración- sino un acto de solidaridad con los postergados, los ignorados, un intento de rescatar del sueño y del olvido al servidor, al hermano. Pero la muerte en el tiempo histórico es irreversible; los sometidos, mutilados y exterminados son irrecuperables. Sólo queda la posibilidad de restablecer la verdad y perpetuarla a través del verbo poético. Neruda no se contenta con el papel de memotialista que escribe la historia verdadera. Como los sumisos no se rebelaron contra sus explotadores, Neruda pide que le transfieran la cólera retenida

5 Compuestas en 1945 , es ésta cronológicamente una de las primeras partes del Canto general. 
durante siglos, que le infundan sus atributos, los propios de la raza mineral, aquélla que no ha roto el vínculo con la tierra materna. Pero va más allá todavía: reclama la consubstanciación corporal, la transfusión sanguínea, para que la sangre del poeta sea sangre de todos y su palabra, palabra de todos; el poeta no será sólo el testificador sino un acicate colérico que incite a la lucha.

Aquí hay un cambio de actitud, pero no de registro. Nótese cómo Neruda sigue utilizando, en una representación no ideal, de intención realista, verista, los mismos mitemas, idénticas imágenes, simbolizaciones semejantes: el tacto que a través de talismanes comunica con las regiones inferiores, con "la eterna veta insondable", las transferencias cualitativas entre todos los órdenes naturales, la tamificación como modelo formativo extensible también a lo humano y a lo mineral, la verticalidad axiológica, los descensos materializantes y los ascensos aligerado. res, los espacios y tiempos sagrados, la homologación entre fecundidad femenina y telúrica, la transubstanciación con las materias maternales, las transmigraciones. Es decir que escribe una poesía igualmente ritual, ceremonial, que la mitológica; reedita recursos de representación que provienen de antiguos valores religiosos, quizá degradados, reducidos a protocolo literario, pero que no pierden su poder de sacralización.

En "El poeta", décimo poema de Las flores de Punitaqui, Neruda vuelve a hunditse, a naufragar. Recuerda la desoladora crisis de Residencia en la tierra, ese desmoronamiento del ser y del mundo que lo enajenó, lo angustió, lo vació, que le hizo tocar el fondo de la muerte. Para representar esa visión desintegradora que preside su poesía anterior reitera los símbolos de la imaginación penetrante, materializante, naturalizante, los del descendimiento regresivo al caos de lo preformal, a las floraciones cenagosas y a las animalizaciones abisales:

Viví un mundo de ciénaga marina en que la flor de pronto, la azucena me devoraba en su temblor de espuma, y donde puse el pie resbaló mi alma hacia las dentaduras del abismo.

Así nació mi poesía, apenas rescatada de ortigas, empuñada sobre la soledad como un castigo, o apartó en el jardín de la impudicia su más secreta flor hasta enterrarla. Aislado así como el agua sombría 
que vive en sus profundos corredores, corrí de mano en mano, al aislamiento de cada ser, al odio cuotidiano. Supe que asi vivian, escondiendo la mitad de los seres, como peces del más extraño mar, $y$ en las fangosas inmensidades encontré la muerte.

Es la muerte del hombre gregario, es la cotidiana usura del aislado, es "una pequeña muerte de alas gruesas", la misma del poema III de $A l$. turas de Macchu Piccbu, la corruptora, la mezquina muerte del hombre de ciudad, la que corresponde a la desvirtuación, a la desnaturalización - ruptura del sagrado vínculo con la naturaleza - inherentes al contexto urbano:

Cuántas veces en las calles de invierno de una ciudad o en un autobús o un barco en el crepúsculo, o en la soledad más espesa, la de la noche de fiesta, bajo el sonido de sombras y campanas, en la misma gruta del placer humano, me quise detener a buscar la eterna veta insondable que antes toqué en la piedra o en el relámpago que el beso desprendía.

No pude asir sino un racimo de rostros o de máscaras precipitadas, como anillos de oro vacío, como ropas dispersas hijas de un otoño rabioso que hiciera temblar el miserable árbol de las razas asustadas.

(Alturas de Maccbu Picchu, II)

En las ruinas de Punitaqui, el poeta reencuentra al hombre pleno, el de la luz intacta -el que conserva la integridad del comienzo-, a la raza metálica, Ia que combate y canta "con la misma unidad de los metales", al pueblo proletario, el que en su cohesión otorga sentido, dirección y dignidad a la vida:

Sólo su resistencia era camino, $y$ aislados eran como trozos rotos de una estrella, sin bocas y sin brillo. Juntos en la unidad hecha en silencio, eran el fuego, el canto indestructible, el lento paso del hombre en la tierra hecho profundidades y batallas.

Eran la dignidad que combatía 
lo que fue pisoteado, y despertaba

como un sistema, el orden de las vidas

que tocaban la puerta y se sentaban

en la sala central con sus banderas.

\section{(Las flores de Punitaqui, XIV)}

El pueblo se convierte para Neruda en el fundamento significativo de toda poesía. Lo concibe como una prolongación de la naturaleza genésica dotado de todas las potestades de la potencia que lo engendra; tendrá los mismos atributos energéticos, la misma capacidad generadora y transformadora que la tierra madre. Para Neruda, la calidad, la cantidad, la intensidad del ser, la consistencia ontológica están siempre en proporción directa con el vínculo natural: a mayor contacto con la naturaleza, más entidad. Todo se refiere en última instancia a la naturaleza, hasta lo político. América indígena es tierra virgen dotada de la plenitud edénica; los naturales, los pueblos indoamericanos son los íntegros que participan de la permanencia de los gérmenes, que poseen la sabiduría del primer día del mundo, el idioma de las estrellas, los secretos del día y de la noche; los conquistadores son los profanadores de la selva original, los portadores de desgracia, los introductores de la religión desnaturalizada y de la tecnología destructora. Los libertadores son ramas del árbol del pueblo, involucrados en el ciclo de las transformaciones vegetales, identificados con las manifestaciones intercambiables de la energía genésica. San Martín es pampa, Bolívar es "metal inaccesible", Juárez es "materia de la profundidad", Martí es almendra, Zapata es semilla. Los opresores, los verdugos, los traidores de América son reptiles, emisarios del mundo de abajo, los animales rastreros, los infernales apenas salidos del caos, de lo preformal, factores de ruptura de la concordia natural, agentes de desorden, regresión, muerte:
Sauria, escamosa América enrollada
al crecimiento vegetal, al mástil
erigido en la ciénaga:
amamantaste hijos terribles
con venenosa leche de serpiente, tórridas cunas incubaron
y cubrieron con barro amarillo
una progenie encarnizada.
El gato y la escorpiona fornicaron
en la patria selvática.

(La arena traicionada, I) 
En las representaciones históricas del Canto general sigue predominando la visión mitológica, el animismo naturalizante. La crónica opera como base de lanzamiento de la energía metafórica que retrotrae siempre la poesía de Neruda hacia el mismo polo de atracción, hacia ese epicentro generador, entrañable, inescrutable, indecible, hacia el principio de los principios. La densidad metafórica, la reiteración de los mismos módulos imaginativos, de los mitemas básicos hace que el texto no pueda leerse como relación de hechos, como crónica o epopeya his. tóricas. Las acciones están revueltas, enmarañadas, invadidas por la turbulencia imaginativa que remite el acontecer humano a instancias mito. lógicas, a las fuerzas cosmogónicas.

En Los rios del canto, los poetas se ligan como una red fluvial, en. troncándose mutuamente, traspasándose sus aguas, "como un árbol de venas". Son poetas naturalizados y naturalizantes. Bajo la advocación de Rafael Alberti, Neruda rememora su conversión de poeta subterráneo, enraizado en las tinieblas a poeta frutal, luminoso, popular. Residencia en la tierra había sido una inmersión disolvente, una caída al despeda. zamiento, una muerte en la hoguera de abajo. A partir de España y merced a la vitalidad mediterránea de Alberti, a su clarividencia de raigambre popular, emerge, recupera la plenitud perdida al reencontrarse con el origen, accede a los gozos del dominio diurno. Simbolismo de las regiones inferiores, verticalidad axiológica, caida, muerte, disolución, regeneración, renacimiento: siempre subyacen los mismos modelos arquetípicos.

En la Carta a Miguel Otero Silva, en Caracas, la poesía se ha convertido en arma que acude al combate callejero. Neruda vuelve a recordar su conversión de subjetivo egocéntrico a poeta de la realidad colectiva, de la individualidad alienada a la conciencia social, de la metafísica evasiva al compromiso con la historia. Las clases opresoras quieren que el poeta se confine en la confesión egoísta, en las tribulaciones amorosas, en la condición de celestial; impiden que sus artistas rompan el círculo áulico de lo permitido, de lo decible, de las conveniencias y las censuras institucionalizadas. Cuando el poeta abandona sus apetencias personales, sus ambiciones privadas, cuando depone su vanidad, cuando se incorpora al pueblo y se asocia a su lucha, los potentados lo reprueban $y$ mandan encarcelarlo:

Pero cuando fui piedra y argamasa, torre y acero, sílaba asociada:

cuando estreché las manos de mi pueblo 
y fui al combate con el mar entero;

cuando dejé mi soledad y puse

mi orgullo en el museo, mi vanidad en el

desván de los carruajes desquiciados,

cuando me hice partido con otros hombres, cuando

se organizó el metal de la pureza,

entonces vino el mal y dijo: "Duro

con ellos, a la cárcel, mueran!"

(Yo soy, XVII)

Por su indeferencia ante el pueblo sojuzgado, los poetas puros se confabulan con los explotadores. Neruda es inclemente con los "poetas celestes", contra ellos lanza una diatriba cargada de colérico menosprecio:

Qué hicisteis vosotros gidistas, intelectualistas, rilkistas, misterizantes, falsos brujos existenciales, amapolas surrealistas encendidas en una tumba, europeizados cadáveres de la moda, pálidas lombrices del queso capitalista, qué hicisteis ante el reinado de la angustia, frente a este oscuro ser humano, a esa pateada compostura, a esa cabeza sumergida en el estiércol, a esta esencia de ásperas vidas pisoteadas?

(La arena traicionada, II)

Los trata de escapistas que buscan evanescencias misteriosas, arrobamientos espirituales, sortilegios verbales, la entrada estremecida en lo sublime, el salto estelar, y que, en realidad, por su prescindencia frente al sistema opresivo, cumplen cobardemente los designios de la clase dominante. Son cortesanos y parásitos de la oligarquía, que los contenta con los detritos del banquete. En Crónica de 1948 (La arena traicionada, IV) e indirectamente en el cuarto poema de Que despierte el leñador, hace el desastroso balance de la situación mundial en la inmediata posguerra, en plena guerra fría; enumera los regímenes dictatoriales de América 
Latina y da cuenta de sus represiones asesinas. Frente a tanta ignominia, Neruda no tolera una literatura autónoma, una poesía que se autoabas. tezca cortando sus contactos con la realidad colectiva. En los medios literarios hispanoamericanos es la época de auge de la poesía pura. La poesía quiere recobrar su sacralidad y sus presuntos poderes, retornar a la trasparencia, acallar los furores vanguardistas y desasirse de la presión de la historia, volver a idealizar la realidad, perseguir exclusivamente la belleza, acceder a los valores intemporales. Dueños de una cultura cosmopolita, al tanto de las novedades europeas, los poetas ce. lestes practican una poesía reticente y refinada, tributaria de las sinestesias simbolistas y en cierta medida de las libertades metafóricas del surrealismo, formalmente contenida y pulcra. La búsqueda de la universalidad se manifiesta a través de una producción no localizada ni temporal ni geográficamente, que elude las referencias a lo circunstancial y circundante. Neruda, en su afán de subordinar lo poético a lo social, condena duramente este silencio cómplice:

Tú qué hiciste? No vino tu palabra para el hermano de las bajas minas, para el dolor de los traicionados, no vino a ti la sílaba de llamas para clamar y defender to pueblo?

(La arena traicionada, IV)

Cuando denuncia las lacras de América, Neruda opta casi siempre por el estilo llano, por el más directo y discursivo. La única hinchazón proviene de su rabia que prodiga denuestos, maldiciones, desprecio ira. cundo, bromas despiadadas. Cuando dice las miserias de los hombres de la tierra, de los parias del campo y la ciudad, de los indios, de los mendicantes su afán es ante todo testimonial, documental. Insiste en que el testimonio proviene de su contacto personal con los damnificados, de una experiencia vivida en sus viajes por América. Busca reforzar la veracidad y la verosimilitud destacando esta calidad de realidad vista y vivida personalmente por el mensajero. Neruda se siente emisor, intermediario de un mensaje colectivo, encomendado por el pueblo a su portavoz, poeta y militante de un partido proletario. El suyo no es conocimiento libresco, sino propia comprobación, auténtica y solidaria vi. vencia. Neruda es antilibresco: 
No escribo para que otros libros me aprisionen ni para encarnizados aprendices de lirio, sino para sencillos habitantes que piden agua y luna, elementos del orden inmutable, escuelas, pan y vino, guitarras y herramientas.

(Yo soy, XX)

Rechaza toda abstracción, todo conocimiento que no implique la participación integral - no sólo mental, sino también corporal, sensorial, sanguínea, glandular-, donde no intervenga el hombre como totalidad indivisible. Para qué, dice, buscar tragedia en la literatura griega, buscar símbolos remotos de la condición humana en las bibliotecas, si las penas del pueblo están al alcance inmediato, golpean del otro lado de la puerta:

(Poeta, buscas en tu libro

los antiguos dolores griegos, los orbes encadenados por las antiguas maldiciones, corren tus párpados torcidos por los tormentos inventados, y no ves en tu propia puerta los océanos que golpean en el oscuro pecho del pueblo.)

\section{(Los libertadores, XXXVIII)}

La actividad textual debe responder impostergablemente a los reclamos políticos, a las urgencias sociales. Las exigencias de la poética militante son rotundas y simplistas, compulsivas.

Como cantor general de América, Neruda se asigna el papel del que testimonia y testifica, el que declara con seguridad y verdad. Me morialista, cronista del pasado, verificador del presente, apologista, censor, condenador y profeta, el poeta debe asumir con exclusividad el papel de portavoz delegado por su pueblo -el pueblo ordena: "Te debes a nosotros,/ eres el que pondrá la marca fría/ sobre los sucios nombres del malvado."- . No sólo evocatá los beneficios de la patria, también tendrá que denunciar a los gusanos que pudren el árbol de la comunidad, que corrompen la comunión de la tierra y sus hombres: 
el dulce privilegio de nombrarte

... No me entregaste, patria, sólo en tus alhelíes y tu espuma, no me diste palabras, patria, para llamarte sólo con nombres de oro, de polen, de fragancia, para esparcir sembrando las gotas de rocio que caen de tu negra cabellera imperiosa: me diste con la leche y la carne las sílabas que nombran también los pálidos gusanos que viajan en tu vientre, los que acosan tu sangre saqueándote la vida.

(Coral de año nuevo para la patria en tinieblas, X)

La visión vuelve a ser naturalizante, tanto de las virtudes aquí telúricas, alimenticias, genésicas, como de sus destructores, gusanos desvitalizadores, provocadores de putrefacción.

Neruda oscila entre la creencia en una misión trascendente, políticamente eficaz, imprescindible, y la conciencia de los límites de una acción textual como factor transformador de la realidad. Por momentos supone que escribe la historia definitiva, la sentencia indeleble:

Gabriel González Videla. Aquí dejo su nombre, para que cuando el tiempo haya borrado la ignominia, cuando $\mathrm{mi}$ patria limpie su rostro iluminado por el trigo y la nieve, más tarde, los que aquí busquen la herencia que en estas líneas dejo como una brasa verde hallen también el nombre del traidor que trajera la copa de agonía que rechazó mi pueblo.

\section{(La arena traicionada, V)}

Otras veces, modestamente advierte la poca capacidad de la escritura poética para operar directamente sobre la realidad exterior, la impoten. cia del poema para arreglar el mundo:

Soy nada más que un poeta: os amo a todos, ando errante por el mundo que amo:

en mi patria encarcelan mineros y los soldados mandan a los jueces. 
Yo no vengo a resolver nada.

Yo vine aquí para cantar

y para que cantes conmigo.

(Que despierte el leñador, VI)

Cuando canta la actualidad, cuando atestigua sobre los males de América, depone sus pretenciones estéticas o las subordina en función de sus deberes de militante político, es decir de exigencias ajenas al texto. La intensidad entonces no está ni en el destinador ni en los signos, sino en lo significado; debe nacer de la realidad comunicada. El poema se neutraliza, quiere adquirir inmediata inteligibilidad, legibilidad popular. Tal es la consigna verbal, la premisa de su escritura. Neruda intenta dejar de ser poeta de lujo, poeta hermético, poeta de minorias:

No soy una campana de tan lejos, ni un cristal enterrado tan profundo que tú no puedas descifrar, soy sólo pueblo, puerta escondida, pan oscuro, y cuando me recibes, te recibes

a ti mismo, a ese huésped tantas veces golpeado

y tantas veces renacido.

(El fugitivo, XII)

Pero esa claridad de nivel popular, le resulta a menudo inalcanzable. Neruda no quiere dejarse aprisionar por otros libros, pero está reducido a utilizar el libro como vehículo de comunicación, el poema como medio expresivo; está sujeto a todas las restricciones de este circuito cultural, cuya difusión casi nunca alcanza las masas: "Escribo para el pueblo aunque no pueda/ leer mi poesía con sus ojos rurales." La oscilación entre exigencia estética y reclamos del militante lo condenan a una con. tradicción irresoluta.

Neruda se autocensura, se autocercena. Abandona el ritual, el verbo oracular, el ámbito sacralizado para intentar una poesía utilitaria, herramienta o arma de la revolución, una poesía proletaria. Los problemas que ella nos plantea siguen vigentes: ¿puede una poesía juzgarse en términos de lucha de clases? ¿la función estética debe subordinarse a 
la ideológica o visceversa? ¿cuál es el valor cognoscitivo de una poesía que renuncia a su función estética en aras de la referencial? ¿vale la pena ampliar la audiencia en detrimento de la especificidad poética? ¿optar por un nivel popular de lectura significa llegar al pueblo? ¿cuál es la eficacia práctica de la poesía política? ¿qué es lo decible y lo indecible poéticos? ¿cómo decir poéticamente lo político?

Neruda no vacila en adoptar formas y contenidos panfletarios; incorpora en bruto (con el mínimo de transformación en signo poético) la doctrina o la propaganda partidista. Cuando se trata de denunciar injusticias, a menudo opta por una poesía grosera para decir verdades gruesas. En La tierra se llama Juan son los mismos protagonistas, agonistas de los abusos, vivos y muertos, que hablan para relatar sus desdichas. Neruda remeda la lengua popular para dar más fuerza, más poder de convicción al mensaje, para provocar la máxima actualización, la máxima impresión de presencia con el mínimo de mediaciones, de distorsiones. En lengua coloquial escasa en metáforas, con pocas trasposiciones de sentido, emplea comparaciones ligadas siempre a la experiencia posible del hablante, reiteraciones propias de un interlocutor de vocabulario reducido, leves modismos regionales:

Sí señor, José Cruz Achachalla, de la Sierra de Granito, al sur de Oruro.

Pues allí debe vivir aún

mi madre Rosalía:

a unos señores trabaja, lavándoles, pues, la ropa.

Hambre pasábamos, capitán,

y con una varilla golpeaban

a mi madre todos los días.

Por eso me hice minero.

(La tierra se llama Juan, IX)

Los poemas de testimonio directo donde comparecen a declarar mujeres y hombres de todo menester y todas las comarcas de América, alternan con las efusiones, con los raptos líricos del poeta que da libre curso a su subjetividad patética, que busca la participación del cosmos en los dolores humanos.

En Neruda no hay análisis político, entiquecimiento interpretativo de la realidad abordada, sino simplificación esquemática, suscinta com. probación. Su finalidad es ante todo dotar a esa realidad de representa- 
ción verbal, su intención es principalmente icónica, vivificadora, personificadora. E1 enemigo es claramente identificado - el imperialismo con sus agentes locales y foráneos- y enjuiciado. La base de la denuncia es elemental porque en esta etapa de la situación latinoamericana (años de redacción del Canto general, 1946 a 1949) las oposiciones son contundentes, las diferencias sociales y económicas abrumadoras, la injusta distribución de la riqueza incuestionable e insoportable. Creo que el intento de Neruda de hacer una poesía documental es a menudo fallido, pero respeto su intención de abandonar la poesía divertimento refinado, juguetería sublime, diapasón selecto para volverla vehículo de una evidencia terrible y prosaica.

Se puede criticar en Neruda su exceso de determinación ideológica, porque sustituye la realidad con su movilidad, su inagotable y heterogénea simultaneidad, su ambigüedad, su inestabilidad, su mutabilidad, por un realismo estrecho, dual, maniqueo, por un determinismo mecánico, dogmático, que nunca encontraremos en su correligionario y contemporáneo César Vallejo.

El Canto general concluye con una autobiografía que procura amal. gamar las dos poéticas, la mítica y la histórica, la visionaria y la mili. tante. Allí confluyen impreganciones de los bosques australes, consubstanciación con las materias maternales, navegaciones y regresos por los mares del mundo y los ríos subterráneos, huracanadas intemperies, mo. vimientos planetarios, germinaciones minerales, floraciones acuáticas, li. mos tempestuosos, urdimbres consteladas, palpitaciones estelares, luces lechosas, labios y uvas terrestres, océanos oscuros, depósitos dormidos, alturas calcinadas, desordenada geología. El hilo de los sueños cosmogénicos se entrecruza con la bondad combatiente, arraigada a la tierra natal, con la solidaridad para los maltratados, con la fraternidad prole. taria:

Quiero que a la salida de fábricas y minas esté mi poesía adherida a la tierra, al aire, a la victoria del hombre maltratado. Quiero que un joven halle en la dureza que construí, con lentitud y con metales, como una caja, abriéndola, cara a cara, la vida, y hundiendo el alma toque las ráfagas que hicieron mi alegría, en la altura tempestuosa.

(Yo soy, XX)

Paris, julio de 1972

SAỨl YURKIEVICH 
